PONTIFÍCIA UNIVERSIDADE CATÓLICA DO RIO DE JANEIRO

\title{
A Relação das Mulheres das Gerações X e Y com Marcas de Moda
}

\author{
Lygia Faiman
}

Trabalho de Conclusão de CuRso

Centro de ciências sociais - CCS

DePARTAMENTO dE AdMINISTRAÇÃO

Graduação em Administração de Empresas 


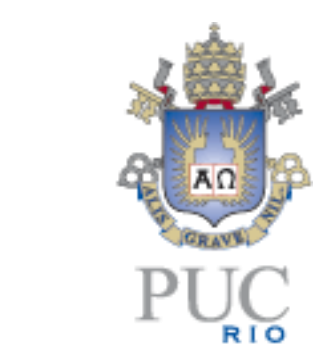

Lygia Faiman

A Relação das Mulheres das Gerações X e Y com Marcas de Moda

Trabalho de Conclusão de Curso

Trabalho de Conclusão de Curso apresentado ao programa de graduação em Administração da PUC-Rio como requisito parcial para a obtenção do título de graduação em Administração.

Orientador: Daniel Kamlot

Rio de Janeiro

junho de 2018. 


\section{Agradecimentos}

Quero agradecer primeiro aos meus pais que, cada um de sua forma, me enchem de amor e são responsáveis pela pessoa que sou hoje.

Aos meus quatro avós e, especialmente, à minha avó Muse, que permitiu que a minha experiência de faculdade fosse exatamente o que eu sempre sonhei.

Aos familiares e, especialmente, aos primos queridos que me trazem tanta alegria.

Às minhas amigas-irmãs, que me acompanham de perto na vida e significam tudo.

Aos meus grandes amigos e parceiros de trabalho da Empresa Júnior PUC-Rio, que verdadeiramente mudaram a minha vida e me fizeram conhecer e reconhecer tanto sobre mim.

À minha gatinha Charlotte, por ser exatamente como é.

Aos meus professores e colegas ao longo desses 23 anos, por todas as experiências que compartilharam e me proporcionaram viver.

Ao meu orientador, por todo suporte e direcionamento. 


\section{Resumo}

FAIMAN, Lygia. A Relação das Mulheres das Gerações X e Y com Marcas de Moda. Rio de Janeiro, 2018. 48p. Trabalho de Conclusão de Curso Departamento de Administração. Pontifícia Universidade Católica do Rio de Janeiro.

O objetivo do presente estudo é compreender as percepções de mulheres das gerações $X$ e $Y$ acerca de marcas de moda feminina. Para isso, foram realizadas dez entrevistas qualitativas, cinco com mulheres pertencentes à geração $X$, com idades entre 38 e 58, e cinco com mulheres pertencentes à geração $\mathrm{Y}$, com idades entre 19 e 37 . As entrevistas buscaram entender a relação dessas mulheres com as roupas, a moda e o posicionamento das marcas de moda, assim como as motivações de consumo e processo de decisão de compra. Os dados coletados foram transcritos e analisados com o intuito de identificar semelhanças e diferenças entre as percepções das mulheres de cada geração, que demonstraram sofrer tanto influências geracionais, quanto particulares.

Palavras-chave

Mulheres; moda; marcas; geração. 


\section{Abstract}

FAIMAN, Lygia. A Relação das Mulheres das Gerações X e Y com Marcas de Moda. Rio de Janeiro, 2018. 48p. Trabalho de Conclusão de Curso Departamento de Administração. Pontifícia Universidade Católica do Rio de Janeiro.

This work aims to understand the perceptions of women from generation $X$ and generation $\mathrm{Y}$ on female fashion brands. In order to pursue this objective, ten qualitative interviews were conducted, five with women from generation $\mathrm{X}$, with ages between 38 and 58 years old, and five with women from generation $\mathrm{Y}$, with ages between 19 and 37 years old. The interviews sought to understand their relationship with clothing, fashion and fashion brand's positioning, as well as the motivations of consumer behavior and buying process. The collected data was transcribed and analyzed in order to identify similarities and differences between the perceptions of women from each generation, who have been shown to suffer both generational and particular influences.

Keywords

Women; fashion; brands; generation. 


\section{Sumário}

1 O tema e o problema de estudo 1

1.1. Introdução ao tema e ao problema do estudo 1

1.2. Objetivo do estudo 3

1.3. Objetivos intermediários do estudo 4

1.4. Delimitação e foco do estudo 4

1.5. Justificativa e relevância do estudo $\quad 4$

2 Revisão de literatura 6

2.1. A Moda 6

2.2. Força das marcas $\quad 7$

2.3. Posicionamento 7

2.3.1. Brand equity 8

2.4. Motivação de consumo 11

2.4.1. Status e bem-estar 12

2.4.2. Comportamento de compra 12

2.5. Gerações 14

2.5.1. Geração X 15

$\begin{array}{lr}\text { 2.5.2. Geração } Y & 17\end{array}$

3 Metodologia 18

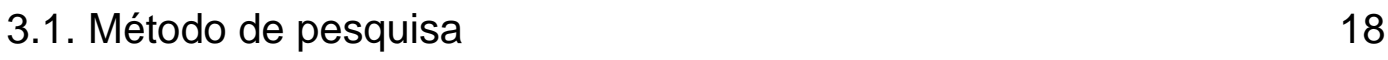

3.2. Seleção de sujeitos 18

3.3. Coleta de dados 19

3.4. Tratamento de dados 20

3.5. Limitação do método $\quad 20$

4 Análise e interpretação dos resultados 22

4.1. A roupa e a moda 22

4.2. Decisão de compra $\quad 25$

4.2.1. Posicionamento de marca $\quad 27$

4.2.1.1. Preocupação social 27 
4.2.1.2. Conteúdo de marca

5 Conclusão

32

5.1. Direcionamento para estudos futuros

34

6 Referências Bibliográficas

7 Anexo 


\section{Lista de figuras}

$\begin{array}{ll}\text { Figura 1: Pilares do Brand Equity } & 10\end{array}$

Figura 2: Hierarquia de Necessidades Humanas $\quad 11$

Figura 3: Modelo de Processo de Compra do Consumidor 13

Figura 4: Segmentação das Gerações por Grupos de Influência no Consumo (Abril, 2016) 16

Figura 5: Os Três Tipos de Propaganda Preferida Focam no Produto (Abril, 2016) 17

Figura 6: Nuvem de Palavras da Geração X 23

Figura 7: Nuvem de Palavras da Geração Y 23 
Lista de Tabelas

Tabela 1: Lista de Entrevistas por Geração 


\section{0 tema e o problema de estudo}

\subsection{Introdução ao tema e ao problema do estudo}

A origem da palavra marca (brand, em inglês) vem do antigo escandinavo "brandr", e significa o ato gravar ou queimar um objeto. Nas primeiras civilizações, passando por Grécia e Roma antiga, já se observa o costume de marcar produtos, tais como peças de cerâmica e gado, a fim de ilustrar a sua origem. Com o passar dos anos e o desenvolvimento do comércio, o conceito de marca passa a funcionar como um atestado de qualidade, dado que o consumidor não comprava mais diretamente do produtor. A partir da Revolução Industrial, no século XIX, surgiram as primeiras leis de garantias às marcas, na Inglaterra, Alemanha e Estados Unidos (PINHO, 1996, p.12). Logo em seguida, com a crise da bolsa norte-americana, em 1929, e o fim da Segunda Guerra Mundial, em 1945, as marcas foram cada vez mais se tornando um mecanismo econômico.

Desde o final do século $X X$, a diversidade de produtos e serviços faz com que a marca ocupe um importante papel no processo de decisão de compra do consumidor (PINHO, 1996, p.8). Para Kotler (1999, p.177) "uma marca é um nome, termo, signo, símbolo ou design, ou uma combinação destes, que tem a função de identificar os bens ou serviços de concorrentes". Atualmente, a tradicional trademark, isto é, a marca registrada, passa a ser substituída pela trustmark, que inspira confiança. Ela não representa apenas um nome ou identidade visual, mas agrega, por si só, verdadeiro valor às organizações. Seu poder na economia é tamanho que pode valer mais do que os próprios ativos tangíveis da empresa (SAMPAIO, 1999, p. 219). Essa tendência é explicada a partir do conceito de brand equity, o que significa o valor patrimonial da marca e sua força traduzida em produtos e serviços.

O processo de construção e gestão de uma marca é definido por branding, que:

"significa dotar produtos e serviços com o poder de uma marca. Está totalmente relacionado a criar diferenças. Para colocar uma marca em um produto, é necessário ensinar aos consumidores quem é o produto batizando-o, utilizando 
outros elementos de marca que ajudem a identificá-lo bem como a que ele se presta e por que o consumidor deve se interessar por ele" (KOTLER, 2005, p.269). 
Nessa ótica, uma estratégia cada vez mais usada pelas empresas para consolidar seu nome entre os consumidores é o emotional branding (ROSSITER \& BELLMAN, 2012). Essa estratégia consiste na construção de um apelo emocional, e não só racional, para gerar identificação da marca com o público.

Em relação ao público consumidor, de acordo com a Nielsen (2016), as mulheres são mais fieis as marcas e gastam maior parte da sua renda disponível com roupas, em relação aos homens. Uma pesquisa realizada pelo portal Women's Marketing (2015) apontou que mais de 35\% delas indicam fazer compras como principal forma de lazer, e $95 \%$ preferem marcas que buscam um relacionamento em longo prazo e se preocupam em agradar seus clientes em momentos além da venda. Dentre as categorias de produtos consumidas, acessórios e artigos de vestuário são destaques.

A relação entre marca, público feminino e moda pode ser justificada pois, de alguma forma, a moda sempre esteve presente no cotidiano feminino, ganhando maior importância a partir da era gótica, no século XIII (Braga, 2008). Do período Barroco, por volta de 1600, à Era Romântica, no século XIX, e Belle Époque no início do século $X X$, as influências culturais e o papel ocupado pela mulher na sociedade refletem diretamente na sua forma de se vestir. Ainda que já existisse uma oferta razoável de mercadorias para atender à distintos gostos, a moda até então era de cunho tradicional e pouco liberal. Contudo, a entrada da mulher no mercado de trabalho e sua valorização fora do ambiente domiciliar provocou uma revolução no mercado de moda feminina. A partir da segunda metade do século $X X$ surgiram grandes nomes de estilistas de luxo, como Coco Chanel e Valentino Garavani, que passaram a vestir celebridades e romper com os tradicionalismos. Nessa época, a moda ganha liberdade e vira, cada vez mais, uma forma de expressão. Dessa forma, observa-se que "a moda, assim, estaria ao mesmo tempo acompanhando e sinalizando as mudanças nos papéis sociais das mulheres" (CALDAS, 1999).

Para a maioria das mulheres, tão importante quanto se sentir bem com uma roupa é a etiqueta que ela carrega. Historicamente, todas as grandes multinacionais da moda surgiram e prosperaram com peças voltadas para 0 público feminino, como é o caso dos grupos $L V M H$ e Kering. Para cativar essas consumidoras, as empresas estão cada vez mais investindo em estratégias para fortalecer o seu valor. Segundo Ries \& Trout (2000), o posicionamento de uma marca não diz respeito ao produto em si, mas sim ao que se faz com a mente do cliente potencial. O Mass Marketing (Marketing de Massa), que busca atingir todos os consumidores com uma única oferta, está perdendo espaço para o One 
to One Marketing (Marketing Customizado). Nessa tendência, as marcas querem se posicionar quase que exclusivamente para cada pessoa, estratégia viabilizada por meio da manutenção dessa relação entre pessoas e empresas. 0 CRM (Customer Relationship Management) é, segundo Kotler \& Keller (2006), o marketing voltado aos relacionamentos individuais com os clientes.

Além disso, outra maneira que as marcas vêm buscando para interagir com o consumidor é por meio de associações com demais empresas e causas. Ao apoiar grupos, organizações ou ideologias, elas esperam que o público se identifique e genuinamente queira fazer parte do universo da marca. Apesar disso, existem diversos outros fatores que interferem nessa escolha, tais como influência digital e publicidade boca-a-boca, principalmente em relação à moda.

Nessa ótica, além das características pessoais de cada consumidora, existem diversos fatores que influenciam a percepção das mulheres sobre as marcas e a moda. Segundo Boone \& Kurtz (2009), os principais aspectos que influenciam o comportamento de consumo são fatores sociais, familiares e culturais. Este último é composto por "um conjunto de valores, crenças, preferências e gostos passados de uma geração para outra" (Boone \& Kurtz, 2009, p.168).

Para Levy \& Weitz (2000),

"um grupo de gerações - pessoas dentro da mesma geração - têm comportamentos de compra similares, pois compartilharam as mesmas experiências e estão no mesmo estágio de vida" (LEVY \& WEITZ, 2000, p. 101).

Por isso, a globalização da economia e modernização da comunicação interferem diretamente nas gerações, afetando o seu estilo de vida, consumo, vida familiar e relação com o trabalho, por exemplo. Assim, as percepções sobre marcas de moda também sofrem essa influência, o que vem transformando como essas empresas se posicionam no mercado. Nesse sentido, em que diferem ou se assemelham as percepções e motivações sobre o consumo de moda entre mulheres de diferentes gerações?

\subsection{Objetivo do estudo}

Diante disso, o objetivo do presente estudo é identificar as diferenças e semelhanças entre mulheres das gerações $X$ e $Y$, em sua motivação para consumir marcas de moda feminina de vestuário. 


\subsection{Objetivos intermediários do estudo}

A fim de aprofundar o direcionamento do estudo, o objetivo principal foi desmembrado nos seguintes objetivos intermediários:

- Analisar a percepção geral do que a moda representa;

- Entender que fatores motivam a escolha por marcas de moda;

- Identificar a influência do posicionamento das marcas de moda na decisão de compra.

\subsection{Delimitação e foco do estudo}

O estudo é direcionado a mulheres cariocas, entre 19 e 37 anos (geração Y) e entre 38 e 58 anos (geração X), que moram nas zonas sul e oeste do Rio de Janeiro. Foram entrevistadas mulheres que já demonstram interesse por moda de vestuário feminino e valorizam, de alguma forma, as marcas desse segmento.

\subsection{Justificativa e relevância do estudo}

A moda é um reflexo da sociedade, segundo Pinho (1996), mas a sociedade também é um reflexo da moda. A mudança na representatividade da mulher, o acesso à informação e os avanços tecnológicos são fatores que influenciam percepções e comportamento de consumo.

Diversas pesquisas vêm sendo feitas para definir características comportamentais das gerações atuais a fim de destacar as diferenças que as influências sociais sofridas por cada grupo de idade promovem. Nesse contexto, o presente estudo exploratório busca identificar as percepções dessas mulheres, pertencentes às gerações $X$ e $Y$, especificamente sobre moda, marcas e consumo, analisando não só fatores geracionais, mas também aspectos inerentes ao estilo de vida e personalidade de cada entrevistada.

Esse estudo se mostra relevante para as marcas de moda feminina, que poderão direcionar estratégias de marketing, por meio do conhecimento de motivações e percepções dessas mulheres acerca da sua relação com a moda.

Também pode contribuir para profissionais do mercado da moda e interessados por comportamento social. Por meio da apresentação de informações sobre a construção das marcas, história da moda, motivações e 
comportamento de consumo de mulheres, pode-se auxiliar fornecendo o fortalecimento do conhecimento destes indivíduos acerca dos temas propostos.

Por fim, o estudo é relevante à academia, já que aborda um segmento específico e pouco explorado que é a relação das mulheres dessas gerações com a moda e o consumo no Rio de Janeiro. 


\section{Revisão de literatura}

\subsection{A Moda}

A palavra moda vem do francês "mode", que significa "uso" e "hábito", originada do latim modus, traduzido como "medida, ritmo, maneira". No dicionário, é definida como "Maneira ou estilo de agir ou de se vestir" e "Sistema de usos ou hábitos coletivos que caracterizam o vestuário, os calçados, os acessórios etc., num determinado momento" (MICHAELIS, 2018).

De acordo com Braga (2008), por meio da moda é possível entender a mente humana, e ela representa muito mais do que a forma de se vestir. Para o autor, ela é "o reflexo de uma época ou da cultura de um povo" (BRAGA, 2008, p.21). A moda é, então, uma forma de representação social que reflete a identidade das pessoas. Ela é responsável pelo bem-estar e forma de expressão individual, mas também permite que coletivos se identifiquem, por isso "é um dos terrenos mais férteis de observação do comportamento social" (CALDAS, 1999, p.11). Para o autor, a palavra pode ser substituída por "mudança", uma vez que promove tendências cíclicas que rapidamente se tornam obsoletas, isto é, a moda é efêmera.

Ao longo do desenvolvimento da sociedade, a vestimenta ocupou diferentes níveis de importância, mas sempre esteve presente no cotidiano da população. "A roupa é vista, antes de tudo, como signo portador de mensagens que nos falam do indivíduo que a veste e da sociedade que a produziu" (CALDAS, 1999, p.29).

A globalização e o desenvolvimento de tecnologias digitais foram fatores que revolucionaram o universo da moda. A facilidade no acesso à informação permite que conteúdos, antes exclusivos de profissionais do mercado ou celebridades, sejam consumidos ao redor do mundo instantaneamente. Desfiles das semanas de moda transmitidos online, backstage de shootings postados no Instagram e os próprios perfis de modelos e blogueiras são exemplos dessa revolução. Para Caldas (1999), a mídia é o "primeiro poder" dessa indústria, visto que possui força para ditar tendências. 


\subsection{Força das marcas}

A intensidade das conexões também impulsionou a circulação de bens, que levou à febre de consumo do século XXI. O poder das marcas ganha ainda mais força com o aumento da oferta. Segundo David Ogilvy (2001), a marca representa as impressões das pessoas que a usam, e é a soma intangível de tudo que o produto envolve, de atributos práticos aos emocionais.

A indústria da moda representa um dos setores em que as marcas são mais relevantes para o consumidor, já que as roupas são como a extensão do corpo. De acordo com o documentário canadense "O Império das Marcas" (Pelletier, 2002), a etiqueta costuma aumentar em torno de $60 \%$ o valor de uma peça de marcas como Louis Vuitton e Nike. Diante disso, pode-se argumentar que:

"uma marca passa então a significar não somente o produto real, mas incorpora um conjunto de valores e atributos tangíveis e intangíveis que contribuem para diferenciá-la daqueles que são similares" (PINHO, 1996, p.7).

Mais do que uma peça de roupa, sapato ou acessório, a marca vende uma ideia. Segundo Kapferer (2008), uma marca é um nome com poder de influenciar os consumidores. Para o autor, a marca é uma ideia compartilhada e desejável incorporada em produtos e serviços. Quanto mais essa ideia for difundida por um maior número de pessoas, mais força a marca tem. Ela ganha poder de influência por meio das associações feitas por consumidores ao pensarem na marca.

Para Pinho (1996, p.51), marcas fortes também podem assumir personalidades, ou seja, é possível identificar nelas características consistentes e humanas. O autor argumenta que "muitas marcas são vistas e descritas como masculinas femininas, simples ou sofisticadas, tradicionais ou modernas. Outras suscitam sentimentos como felicidade, confiança, segurança (...)". Segundo Ries \& Trout (2000), a construção de uma marca não é o que se faz com um produto, mas sim o que se constrói na mente do consumidor. Nesse sentido, para conquistar um share of mind, ou seja, efetivamente ocupar um espaço no pensamento das pessoas, é preciso desenvolver uma marca forte.

\subsection{Posicionamento}

Segundo Ries \& Trout (2009) a evolução do conceito de posicionamento é reflexo de uma sociedade supercomunicativa, com excessos de estímulos e 
mensagens promovidos por instituições. Buscando diferenciação entre as demais, as marcas recorrem ao posicionamento como uma forma de segmentar o seu mercado, além de se destacar perante as empresas concorrentes.

Para Oliveira \& Campomar (2006) o posicionamento é fundamental porque permite que os consumidores desenvolvam percepções acerca de determinada marca. Para Jucá \& Jucá (2009), existem dois conceitos que envolvem a relação das empresas com o público, que são: a identidade e a imagem. A identidade de uma marca são os elementos usados por ela para gerar impressões no público, ou seja, as percepções que a marca espera causar. Por outro lado, "como de fato a marca é percebida, por sua vez, constitui a imagem de marca" (JUCÁ; JUCÁ, 2009, p.16). Um posicionamento de sucesso acontece quando esses aspectos estão alinhados, e, assim, a imagem que a marca possui é compatível com a sua identidade.

Uma ferramenta que faz parte da construção do posicionamento são os benefícios que determinada marca oferece. Segundo Keller (1993) eles representam o valor que os consumidores atribuem a produtos e serviços. Esses benefícios podem ser funcionais, experimentais e simbólicos. Os primeiros são relativos a vantagens da mercadoria em si e costumam envolver necessidades básicas e soluções de problemas dos compradores. Já os benefícios experimentais se referem ao que o consumidor sente ao usar o produto ou serviço, mas também atrelado às características desses. Os benefícios mais extrínsecos ao produto ou serviço são os simbólicos, que correspondem a necessidades subjacentes dos consumidores, como autoestima, aprovação social e expressão.

Para Heine (2010), as estratégias de diferenciação das marcas estão sendo mais focadas nos benefícios simbólicos. Como consequência, os consumidores escolhem um produto cada vez mais por semelhanças e alinhamento entre as suas características e valores pessoais com as do objeto ou marca.

\subsubsection{Brand equity}

De acordo Aaker (1998), o valor de uma marca advém do conceito de brand equity, que significa:

"o conjunto de ativos e passivos ligados a uma marca, seu nome e seu símbolo, que se somam ou se subtraem do valor proporcionado por um produto ou serviço para uma empresa e lou para os consumidores dela. Para que certos ativos e 
passivos determinem o brand equity, eles devem estar ligados ao nome e/ou símbolo da marca" (AAKER, 1998, p. 16).

Para Keller e Machado (2006), quando um consumidor reage mais favoravelmente à um produto por saber a sua marca, o brand equity é positivo. $\mathrm{A}$ manutenção do brand equity é responsável pela vantagem competitiva e garante a rentabilidade a longo prazo.

As pessoas tendem a preferir o que lhes é familiar. Isso significa que, segundo Aaker (2014), se uma marca é reconhecida, existe um motivo para isso. Uma maneira de medir notoriedade é por meio do share of mind. Uma marca forte costuma ocupar o top of mind, ou seja, não só está presente na mente do consumidor, mas é a primeira a ser lembrada. No universo da moda, é comum citar o nome da etiqueta antes do produto - por exemplo, ao invés de falar de uma bolsa, só se fala de Prada.

A percepção de qualidade de uma marca pode representar aspectos diferentes, dependendo da indústria em que o produto está inserido. Ela envolve tanto aspectos relacionados à mercadoria quanto ao serviço prestado pela empresa, por isso é preciso analisá-los separadamente (AAKER, 1998).

Segundo Garvin (1995), as oito dimensões de qualidade são: desempenho, características, conformidade, confiabilidade, durabilidade, atendimento, estética e qualidade percebida. O desempenho está relacionado aos aspectos funcionais e mensuráveis do produto, enquanto as características representam fatores secundários, que complementam sua função básica. A conformidade se refere ao nível em que as características do produto atendem aos padrões estabelecidos. A confiabilidade é relativa à probabilidade de falha ou mau funcionamento. A durabilidade é a vida útil do produto. $\mathrm{O}$ atendimento engloba todos os fatores que envolvem essa dimensão e podem influenciar a percepção do consumidor. Já a estética envolve percepções e julgamentos individuais acerca da aparência, essência e até sentimento que o produto provoca. Já a qualidade percebida é representada pela reputação de um produto. Por exemplo, é comum que se uma marca que possui uma boa reputação lançar um novo produto, os consumidores considerarão que ele é bom mesmo sem ter testado, devido à imagem já criada da marca. Por fim, importância de cada uma dessas dimensões varia conforme as características pessoais de cada consumidor, e a marca pode investir recursos se posicionando com base em algumas delas.

Outro fator importante para a construção do valor de uma marca são as associações. Para Aaker (2014), elas podem ser a base do relacionamento com 
o consumidor, da decisão de compra, da experiência e da lealdade. Isso significa que seu valor se estende para aspectos além do produto físico. As marcas podem se associar a personalidades, músicas e lugares, por exemplo.

Por fim, Aaker (1998, p. 16) define alguns pilares-chave para a construção de uma marca forte, que são resumidos em conhecimento da marca, qualidade percebida, associações, lealdade do consumidor e outros ativos como patentes e trademarks, conforme a figura abaixo.

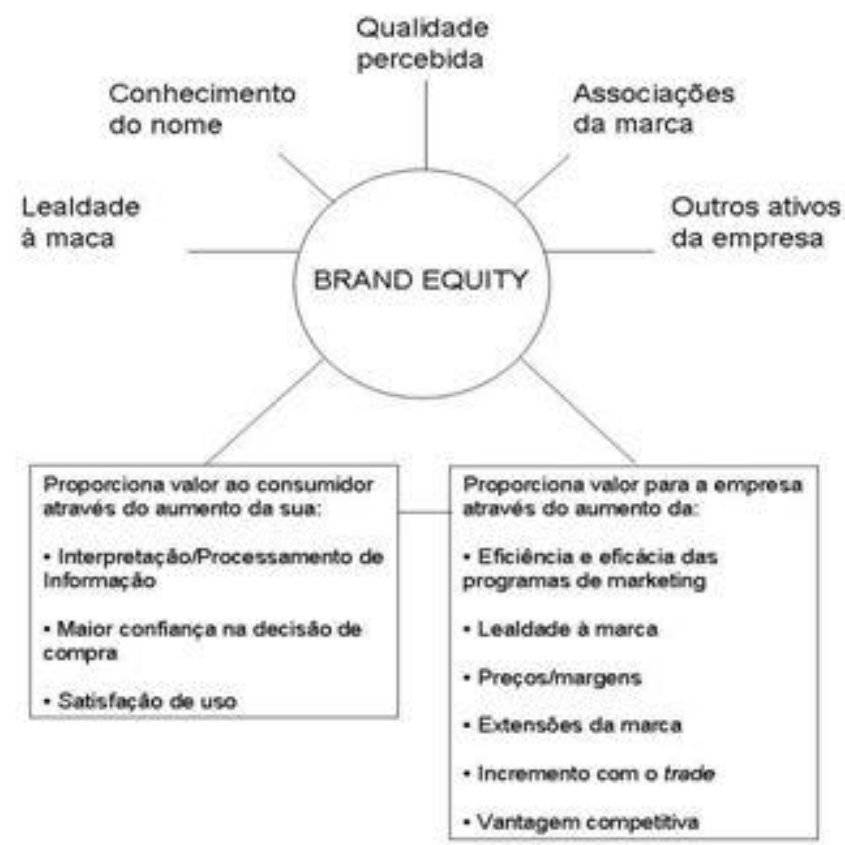

Figura 1: Pilares do Brand Equity

Segundo o autor, as categorias que compõem o brand equity acrescentam valor tanto para os consumidores quanto para as marcas:

"Podem também afetar a confiança do consumidor na decisão de compra (...) tanto a qualidade percebida como as associações da marca podem aumentar a satisfação do consumidor com a experiência de utilização" (AAKER, 1998, p. 17).

Já para as empresas, o brand equity pode ressaltar a lealdade à marca, que, por sua vez, é um elemento fundamental, já que uma vez obtida, dificilmente será transferida para outro concorrente (AAKER, 2014). Por isso, conquistar a fidelidade do consumidor garante a continuidade da marca, já que "a fidelidade à marca se reflete aproximadamente na taxa de retenção dos clientes" (KOTLER, 2003, p. 73). 


\subsection{Motivação de consumo}

Como a moda representa muito além de uma peça de vestuário, as motivações atreladas ao consumo desse tipo de produto envolvem diversos aspectos. Nesse sentido, as marcas precisam adotar estratégias que conquistem o consumidor. Então, "para fascinar e emocionar as pessoas, vale se de conhecimentos oriundos da psicologia e da sociologia" (COBRA, 2007, p. 67). Evidentemente, existem diversos fatores psicológicos que podem explicar as sensações presentes no consumo, envolvendo necessidades utilitárias, racionais e hedônicas ligadas a satisfações emocionais.

Diante disso, Maslow classificou as necessidades humanas a partir de uma hierarquia. Segundo o autor, as pessoas possuem cinco categorias de necessidades básicas pelas quais são motivadas. Elas são: fisiológicas, segurança, afirmação, autoestima e autorrealização. De acordo com essa pirâmide, só é possível avançar de uma categoria para a seguinte da hierarquia na medida em que a anterior está sendo satisfeita.

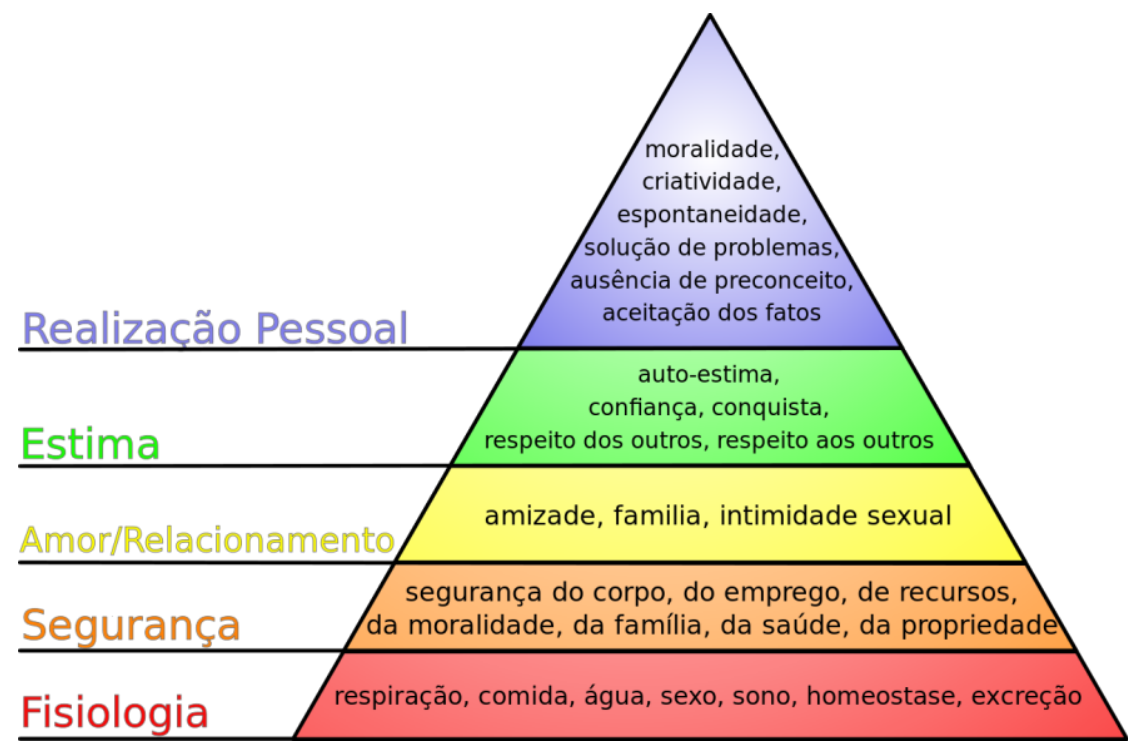

Figura 2: Hierarquia de Necessidades Humanas

Em outras palavras, resumidamente, só é possível almejar realizações pessoais e sonhos uma vez que haja confiança e reconhecimento por parte dos outros, o que só é alcançado caso o indivíduo tenha relações sociais, mas, antes disso, deve-se satisfazer às necessidades de segurança, tais como estabilidade e saúde. Finalmente, a primeira categoria que motiva as pessoas, e é a base para que todas as outras possam acontecer, está relacionada a sobrevivência, por meio de fatores como respiração e alimentação. 


\subsubsection{Status e bem-estar}

No universo da moda, para aqueles cujo a roupa significa mais do que simplesmente suprir a obrigação de se vestir, as motivações para essa atividade podem estar relacionadas às necessidades sociais e de bem-estar - as duas últimas categorias da pirâmide (Figura 2). Essas necessidades são consideradas não básicas, uma vez que, segundo Lipovetsky (2001, p.171) "jamais se consome um objeto por ele mesmo ou por seu valor de uso, mas em razão (...) de prestígio, do status, da posição social que confere".

Nesse sentido, a roupa não é só um artigo funcional, e a marca transcende as características da peça e instiga fatores emocionais no consumidor. Ao adquirir um produto, busca-se sempre uma recompensa, que pode estar ligada a fatores internos ou externos como "mediar nossas relações sociais, nos conferir status, construir identidades e estabelecer fronteiras entre grupos e pessoas." (BARBOSA, 2006, p.22)

As necessidades de cada indivíduo estão diretamente relacionadas às relações e influências que esse recebe desde a infância. De acordo com Higgins (1987) e a Teoria das Discrepâncias do Eu, existe o eu real, que são as características do indivíduo, o eu ideal, que inclui desejos e esperanças, e o eu obrigatório, que representa aspectos que a pessoa deveria ter.

Segundo Sheth et al. (2001), o ato de consumir sempre satisfaz uma necessidade. Esta é motivada pela noção de autoconceito, que engloba tanto o que a pessoa de fato é, quanto o que ela gostaria de ser, com base na percepção dos outros. Especialmente na moda, esse conceito está diretamente atrelado ao consumo, uma vez que "a roupa integra o físico, que é o corpo, e o sentimento, que é o espírito. As pessoas gostam de ser notadas e admiradas, em um misto de orgulho e vaidade" (BRAGA, 2008, p.71).

\subsubsection{Comportamento de compra}

Segundo Solomon (2016, p.6), o comportamento do consumidor:

"é o estudo dos processos envolvidos quando indivíduos ou grupos selecionam, compram, usam ou descartam produtos, serviços, ideias ou experiências para satisfazerem necessidades e desejos" (SOLOMON, 2016, p.6). 
Segundo o autor, embora o momento da transação entre pessoa e empresa ser fundamental nesse processo, o estudo do comportamento do consumidor é contínuo e envolve diversas etapas.

Já para Boone \& Kurtz (1998), para compreender o comportamento do consumidor é preciso analisá-lo como um processo de decisão. Os consumidores passam por esse processo buscando satisfazer suas necessidades, que sofrem diversas influências. De acordo com Churchill \& Peter (2007, p.65), as etapas deste processo estão resumidas abaixo:

\section{Modelo de Processo de Compra do Consumidor}

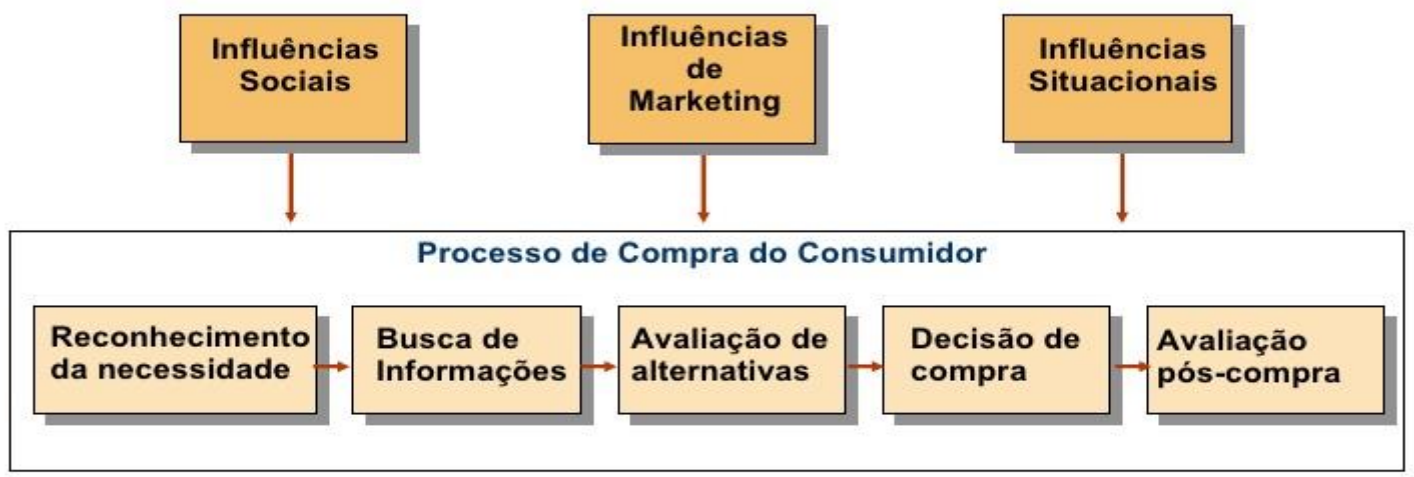

Figura 3: Modelo de Processo de Compra do Consumidor

Segundo Boone \& Kurtz (1998, p.184-187), o reconhecimento do problema acontece quando o consumidor percebe uma diferença entre uma situação atual e a desejada. Nesse momento, o indivíduo se sente motivado em sanar essa defasagem identificada. Assim, o consumidor busca obter informações sobre como alcançar o estado desejado por meio de pesquisas internas e externas. Isso significa que ele pode se apoiar nas próprias informações que já possui dentro de si para embasar a decisão de compra, ou complementá-la com referências externas. A partir disso, avalia-se as alternativas encontradas na busca anterior e, então, é tomada a decisão de compra e a realização do ato. Por fim, a conclusão desse processo pode levar à satisfação ou insatisfação do consumidor, dependendo se sua necessidade inicial foi sanada ou não.

Para Churchill \& Peter (2007), deve-se considerar diversos fatores que influenciam o processo de decisão de compra, que são subdivididos em 
influências sociais, de marketing e situacionais. De acordo com o autor, o primeiro fator - as influências sociais - envolve os diversos grupos que influenciam o consumidor de forma direta e indireta. Nessa divisão, entram os aspectos culturais, ou seja, os valores e comportamentos compartilhados por determinada época em uma sociedade. Isso denota que o comportamento de compra pode divergir entre as gerações, já que sofrem influências culturais diferentes. Nesse grupo, também entram os grupos de referência, que são "pessoas que influenciam os pensamentos, sentimentos e comportamentos dos consumidores" (CHURCHILL, 2007, p.160), que podem ser amigos, familiares e celebridades, para citar alguns exemplos.

Um outro fator ressaltado são as influências de marketing, compostas pelas atividades de marketing promovidas pelas empresas que interferem no processo de compra (CHURCHILL \& PETER, 2007, p.164). Segundo Solomon (2016), as marcas usam estratégias como propagandas, embalagens e site, buscando influenciar o consumidor que compartilha determinado estilo de vida. Para o autor, o consumidor acredita que "comprando e usando um produto, absorverá suas qualidades" (SOLOMON, 2016, p.6), daí a força de influência do posicionamento das marcas.

Por último, as influências situacionais também podem alterar o processo de compra do consumidor. Segundo Churchill \& Peter (2007), elas correspondem a fatores como: o ambiente físico, ou seja, as características de uma loja, por exemplo; o ambiente social, que envolve as interações entre pessoas; o tempo; e condições momentâneas, como o humor do consumidor no momento.

Analisando especificamente o mercado de moda, os fatores que influenciam o comportamento de compra são diversos. Para Caldas (1999), é difícil prever o ato da compra nesse universo, pois é fortemente determinado por cunho pessoal e, muitas vezes, os fatores aparentemente irracionais prevalecem sobre os racionais e objetivos.

\subsection{Gerações}

De acordo com Smola \& Sutton (2002) uma geração é definida por um grupo de pessoas que compartilha anos de nascimento e vivencia experiências recebendo influências em estágios semelhantes da vida. Elas são determinadas por características comportamentais provocadas por impactos sociais, 
econômicos e tecnológicos. Esses grupos, em maior ou menor grau, apresentam padrões de comportamentos em relação à vida, trabalho e consumo.

Atualmente, as duas gerações que compõem a PEA (população economicamente ativa) do Brasil são as gerações $\mathrm{X}$ e $\mathrm{Y}$, que compõem o objeto estudo do presente trabalho.

\subsubsection{Geração X}

A geração X corresponde aos nascidos entre 1960 e 1980 (BASTOS, 2012). Para Fernandes (2015), foi a partir dessa geração, com o perfil mais individualista que as anteriores, que as marcas precisaram se preocupar com a segmentação do mercado em menores nichos. Além disso, segundo a autora, "esta geração teve muito forte a presença de ídolos e baseiam suas opiniões e vestimentas em ícones de moda influenciados pelo avanço do marketing e da publicidade".

Uma pesquisa realizada pelo Grupo Abril (2016) denominada " $O X$ da Questão" destacou algumas características desse grupo frente ao consumo. De acordo com a pesquisa, $77 \%$ deles focam mais nas características do produto do que em ideias ou causas. Apenas 15\% preferem experiências inspiradoras e surreais a simulações de produtos e serviços na vida real. Além disso, essa geração é mais propensa a pesquisar e ler informações antes da compra, bem como materiais que ensinem sobre o produto ou serviço.

Em relação à renda, seu gasto per capita em artigos de vestuário é $66 \%$ maior do que o da geração $Y$. A geração $X$ também é responsável por $51 \%$ da renda gerada pelas famílias no Brasil, e exerce maior influência nas decisões de compra. A Figura 4 retrata a diferença nas influências de consumo das gerações, a partir de perfis classificados como influenciado, decisão individual, decisor conjunto, decisor do lar e influenciador. 

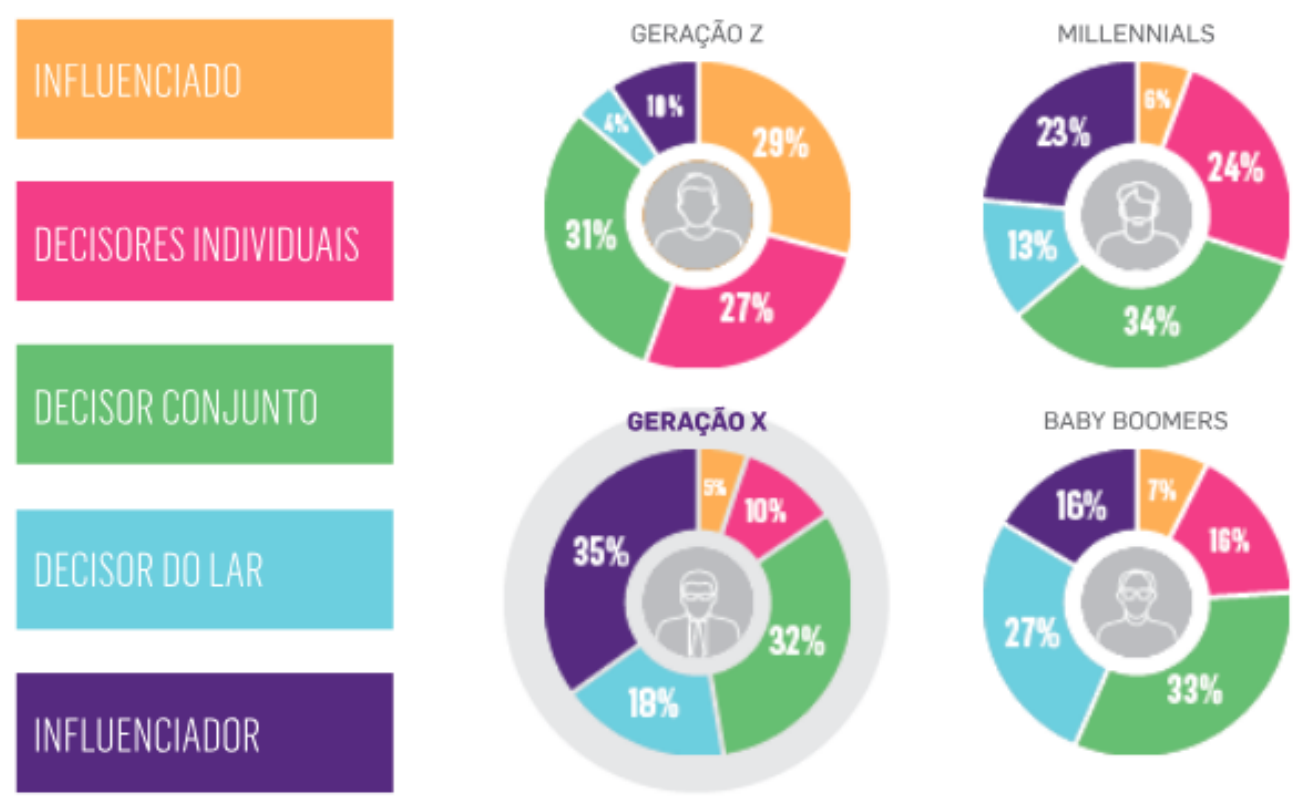

Figura 4: Segmentação das Gerações por Grupos de Influência no Consumo (Abril, 2016)

Para finalizar, o estudo ainda apontou que essa geração prefere uma comunicação direta e honesta quando relacionada a produtos e serviços, não se preocupando tanto com associações e ideologias expressas pelas marcas. A Figura 5 ilustra as preferências na abordagem de produtos e serviços dessa geração:

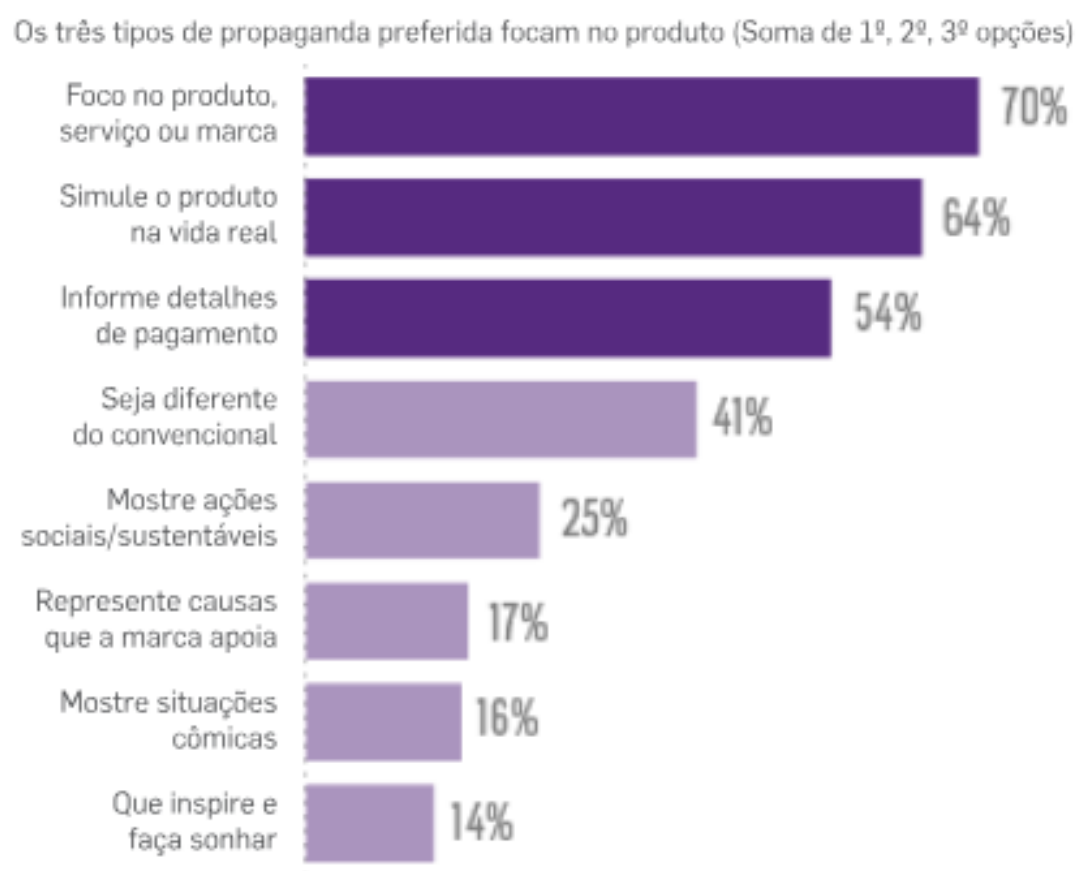


Figura 5: Os Três Tipos de Propaganda Preferida Focam no Produto (Abril, 2016)

\subsubsection{Geração $Y$}

A geração $\mathrm{Y}$, comumente conhecida como Millennials, corresponde aqueles nascidos entre 1981 e 1999 (BASTOS, 2012). Devido a intensificação da globalização e os avanços na comunicação, essa geração possui comportamentos de consumo diferentes da anterior. Para essa geração, o acesso à informação é relevante na reflexão sobre o consumo.

"Com tanto conteúdo na sua vida, perderam a referência nos ídolos inalcançáveis e são realistas, se inspiram em pessoas comuns como uma busca pela identificação que perderam na infinita possibilidade de referências. Os blogs de moda são um grande exemplo disso" (FERNANDES, 2015).

Segundo o Relatório "Bens de Consumo Conectados de 2016" realizado pela Salesforce (2016), essa geração é mais propensa a confiar em interações com as marcas nas redes sociais (JEFFREYGROUP BRAZIL, 2016). Além disso, eles são a geração que menos tem reações negativas as propagandas no meio online. A propensão à participar de programas de fidelidade também é maior na geração $\mathrm{Y}$, denotando que são mais leais às marcas. Ainda de acordo com o relatório, $41 \%$ das pessoas entrevistas dessa geração afirmam que forneceriam informações pessoais para uma empresa a fim de obter serviços personalizados (JEFFREYGROUP BRAZIL, 2016).

Para a pesquisa realizada pelo Grupo Abril (2016), os millennials estão constantemente conectados as redes sociais buscando novas tendências e causas para apoiarem e se identificarem. Eles se preocupam com mais características do que apenas o produto ou serviço em si, preferindo consumir conteúdos objetivos que os engajem, e, ainda, que tenham maior apelo emocional. 


\section{Metodologia}

A fim de alcançar o objetivo proposto por este presente trabalho, além da consulta à dados secundários por meio de livros, artigos, teses e sites, também foi realizada uma pesquisa primária a partir da coleta de entrevistas de pessoas previamente selecionados para a pesquisa. Segundo Mattar (2005), esse é o tipo de coleta de informações que nunca foram coletadas ou analisadas, e são fontes específicas para o estudo.

\subsection{Método de pesquisa}

A metodologia desta pesquisa realizada é de caráter exploratório. Segundo Gil (1999, p.45), pesquisas exploratórias têm como objetivo fornecer uma visão geral e próxima do tópico aprofundado. Elas costumam ser realizadas a partir de entrevistas ou estudos de caso. Nesse sentido, o estudo qualitativo permite esclarecer e desenvolver conceitos e ideias acerca do tema.

Buscando identificar semelhanças e diferenças entre as gerações $X$ e $Y$ em relação às suas percepções sobre marcas e consumo de moda, elaborou-se um roteiro de entrevista semi-estruturado. Segundo Manzini (2004), essa técnica consiste na estruturação de perguntas principais, que podem ser aprimoradas conforme $o$ andamento e fatores momentâneos da entrevista.

\subsection{Seleção de sujeitos}

Para este presente estudo, foram escolhidos sujeitos pertencentes à dois grupos etários diferentes. Ambos são formados por cinco mulheres, residentes do Rio de Janeiro. Representando a geração $X$, foram entrevistadas mulheres que possuem entre 38 e 58 anos. Já as mulheres da geração $Y$ possuem entre 19 e 37 anos. Todas as entrevistadas possuem o hábito de comprar roupas de moda de diferentes marcas. 
As entrevistas aconteceram de forma individual, no qual os únicos critérios considerados para a escolha foram os apresentados acima. Em seguida, a Tabela 
1 apresenta a distribuição das participantes a partir das iniciais de seus nomes e suas respectivas idades. A escolha de manter as iniciais do nome se justifica para proteção e garantia do anonimato de cada uma delas.

\begin{tabular}{|c|c|}
\hline \multicolumn{2}{|c|}{ Geração X } \\
\hline Iniciais & Idade \\
\hline M.V. & 55 \\
\hline M.P. & 53 \\
\hline D.M. & 49 \\
\hline L.M. & 48 \\
\hline C.R. & 42 \\
\hline \multicolumn{2}{|c|}{ Geração Y } \\
\hline Iniciais & Idade \\
\hline P.W. & 34 \\
\hline T.L. & 30 \\
\hline A.L. & 23 \\
\hline F.M. & 20 \\
\hline L.T. & 20 \\
\hline
\end{tabular}

Tabela 1: Lista de Entrevistas por Geração

\subsection{Coleta de dados}

Inicialmente foram realizadas pesquisas em fontes de dados primários, em caráter bibliográfico e previamente exibidos do referencial teórico, a fim de aprofundar o conhecimento sobre moda, marcas, comportamento de consumo e gerações. Procurou-se entender a história da moda e do desenvolvimento das marcas, até o brand equity e força que pode representar perante aos consumidores. Mostrou-se relevante, também, a análise da importância das marcas para o público feminino, bem como aspectos da motivação do consumo de moda. Por último, buscou-se informações sobre o comportamento de consumo entre as gerações $\mathrm{X}$ e $\mathrm{Y}$.

Em seguida, foi realizado o estudo qualitativo a partir de um roteiro de entrevistas ${ }^{1}$, com cinco mulheres de cada grupo geracional. O objetivo foi identificar características pertencentes a cada grupo. As perguntas abordavam questões como a importância da moda, representatividade e posicionamento das

\footnotetext{
${ }^{1}$ Para maiores informações sobre o roteiro das entrevistas, ver Anexo 1 do presente trabalho.
} 
marcas, motivações para escolha e preocupação com momentos além da compra.

Todas as entrevistas foram agendadas previamente e foram desenvolvidas durante o mês de maio de 2018 pela autora deste trabalho. Com o consentimento e autorização das entrevistadas, elas foram gravadas e transcritas para melhor aproveitamento dos dados coletados.

\subsection{Tratamento de dados}

De acordo com Godoy (1995, p.58), "a pesquisa qualitativa não procura enumerar e/ ou medir os eventos estudados, nem emprega instrumental estatístico na análise dos dados". Seu objetivo envolve trazer informações a partir da interação entre o pesquisador e a situação analisada, seguindo a perspectiva dos participantes.

Dessa forma, os dados foram analisados a fim de identificar a percepção de cada geração a partir do mesmo roteiro. Para isso, a análise de discurso foi usada para o tratamento dessas informações. Segundo Vergara (2005, p.25), "a análise do discurso é um método que visa não só aprender como uma mensagem é transmitida, como também explorar o seu sentido". Por isso, esse tipo de metodologia foca no estudo de palavras e expressões, considerando o contexto, emissor e destinatário do conteúdo e, sobretudo, "deve-se preservar a fala dos participantes". Nesse sentido, as informações foram agrupadas de forma a destacar não só as percepções das mulheres sobre cada tema, mas também as semelhanças e diferenças entre cada faixa geracional.

\subsection{Limitação do método}

O presente estudo possui certas limitações em relação à pesquisa, segundo Malhotra (2005), ela está sujeita ao momento da entrevista, além de características pessoais do aplicador. Essa abordagem pode abrir margem para interpretações errôneas. As entrevistas qualitativas também consideram verdadeiras as respostas expostas, porém não é possível atestar a veracidade dessas informações.

Também vale ressaltar que o estudo foi realizado somente com mulheres, visando considerar o objetivo proposto de analisar a relação entre moda e 
consumo das gerações $\mathrm{X}$ e $\mathrm{Y}$ do público feminino. Além disso, as conclusões obtidas não são quantificáveis nem generalizáveis, visto que a própria natureza de pesquisa escolhida é, segundo Malhotra (2005), baseada em amostras não representativas e, logo, não podem ser analisadas estatisticamente. 


\section{Análise e interpretação dos resultados}

Após a realização das entrevistas, todas as respostas foram transcritas visando facilitar a organização e interpretação dos dados. A seguir, serão apresentadas as análises em dois blocos principais, o primeiro envolvendo percepções sobre roupas e moda em geral, e, o segundo, sobre a decisão de compra, subdividido em posicionamento de marca, preocupação social e conteúdo promovido pelas marcas. Em cada tópico, serão expostos destaques da geração $X$ e da geração $Y$, identificando semelhanças e diferenças.

\subsection{A roupa e a moda}

Para iniciar a conversa e envolver as mulheres na temática da entrevista, a primeira pergunta teve como objetivo primordial identificar as principais palavras e expressões que vêm à mente ao ouvir o termo "roupa". Segundo Caldas (1999), conforme já argumentado, a roupa é um ato de comunicação que retrata o indivíduo. Para todas as entrevistadas de ambas as gerações, as palavras em comum que se destacaram foram moda e estilo. Para Mesquita (2009, p. 22-23), o estilo é um dos principais aspectos da moda atual, que expressa relações com o corpo e a aparência.

Todas palavras citadas pelas mulheres entrevistadas estão representadas nas "nuvem de palavras" ilustradas nas Figuras 6 e 7 em seguida, na qual o tamanho de cada uma retrata a frequência em que foi citada. Por isso, algumas palavras possuem maior destaque que outras, implicando na maior frequência do seu uso nas entrevistas. A primeira "nuvem" corresponde às entrevistadas da geração $X$, e a segunda, às da geração $Y$. 


\section{Despojada}

Moda $a_{\text {Expressão Escolha }}$

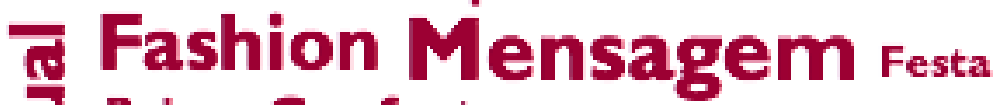
Uु Qualidade Luxo $>$ Vis Estilo

Figura 6: Nuvem de Palavras da Geração X

\section{Moda Necessidade

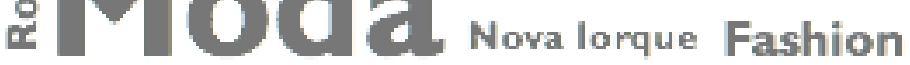 Loja Luxo Personalidade Lifestyle}

Marca Expressão Conforto Consumo Imagem

Figura 7: Nuvem de Palavras da Geração Y

Aprofundando a percepção dessas mulheres sobre o conceito de moda, elas foram indagadas sobre o que as marcas de moda representam. Diante disso, as respostas da geração $X$ foram diversas entre si. Todavia, todas destacaram que essas marcas representam "estilo" de alguma forma. Segundo Caldas (1999) e Braga (2008), a moda é efêmera, representando tendências sociais, percepções essas que foram citadas por algumas entrevistadas. Para a D.M., elas podem até simbolizar "mudança e reinvenção". Já a entrevistada M.V. disse que a influência que as marcas de moda exercem pode variar de tempos em tempos. Segundo ela:

"As marcas me influenciam porque gosto do estilo de algumas, até de alguns momentos de algumas marcas, quando elas ficam mais dentro da minha linguagem e do meu estilo. Tenho sonho e vontade de comprar uma marca quando isso acontece" (M.V., 55 anos). 
O significado de marcas de moda também desperta percepções diferentes de acordo com a personalidade das entrevistadas da geração Y. Para algumas delas, as marcas não são percebidas com um aspecto importante ou até positivo. Especificamente, A.L. disse que ter uma roupa de uma marca específica não significa nada para ela, pois a mesma valoriza a peça em si. Enquanto isso, a F.M contou que a expressão "marcas de moda" Ihe causa estranhamento. Observa-se alguns trechos que reforçam esse ponto:

\footnotetext{
"Ter roupa de marca específica não significa muito [pra] mim, é muito mais a peça em si. O nome de uma marca hoje em dia não me faz querer ter, até as grifes mais caras hoje não fazem meus olhos brilhar, é a peça." (A.L., 23 anos).
}

"Engraçado que é um termo que me dá certo afastamento, eu sinto uma coisa meio excludente. Me remete as empresas grandes e tradicionais de luxo que já tem muito poder no mercado, eu associo marcas de moda com marcas de luxo." (F.M., 21 anos).

Uma das entrevistas, T.L., destacou que as marcas de moda muitas vezes representam algo além das peças, seja inovação, criatividade, arte e história. Essa percepção remete à Caldas (1999), que considera fatores como sociedade e arte para explicar o surgimento da história da moda. Para a concepção de marcas de moda para L.T., a identificação é um elemento importante, pois ela acredita que as marcas podem inspirar um estilo de vida. Isso denota a busca por fatores extrínsecos à peça de roupa, que são considerados pelos consumidores em busca de recompensas emocionais promovidas pelas marcas (BARBOSA, 2006).

\footnotetext{
"[Pra] mim a marca de moda representa uma forma de identificação. Quando olho uma marca que não vejo identificação e não consigo entender, isso me frustra e não me atrai. Gosto de marcas que têm o seu próprio estilo de vida e que sei o que vou encontrar nela" (L.T., 20 anos).
}

Em relação à preocupação com os amigos e familiares na escolha das marcas de moda, observou-se que nenhuma das entrevistadas demonstrou considerar essas opiniões quando deparadas com a escolha da marca. No entanto, em contrapartida, essa preocupação foi relevante quando considerado em relação a peça de roupa em si. Como a roupa é uma forma de expressão, ela está intimamente ligada ao autoconceito, que, segundo Sheth et al. (2001), envolve não só as características particulares da pessoa, mas também o que ela é perante a percepção dos outros. Nesse sentido, a busca por aprovação de amigos e familiares denota influência de grupos de referência no comportamento de decisão de compra (CHURCHILL \& PETER, 2007). 
Nesse sentido, as entrevistas M.V. e L.M., da geração $X$, recorrem às filhas quando estão em dúvida sobre comprar ou não alguma coisa. Já a M.P. destacou uma outra questão, a saber: a percepção das pessoas no seu ambiente de trabalho sobre as o que veste, e como isso influencia na escolha da roupa no dia-a-dia. Enquanto isso, a F.M. e a P.W., da geração Y, têm o costume de pedir opiniões especialmente no momento de usar a roupa, depois de já terem comprado a peça. Isso denota que, embora as decisões de compra partiram de um âmbito mais individual para essas entrevistadas, elas ainda consideram a influência de amigos ou parentes na hora de efetivamente usar a roupa, reforçando, portanto, a importância de percepções externas na construção do seu autoconceito.

"Não muito, eu até peço quando estou na dúvida uma opinião, mas é uma coisa que eu mesma decido. Mas, por exemplo, no meu trabalho, eu acompanho o estilo de roupa que uso conforme o tipo de cliente. Faço um trabalho assim para que a pessoa se sinta à vontade, porque sei que muitas vezes a forma de vestir influencia" (M.P., 53 anos).

"Na marca zero, mas na peça, sim. Até mando [pras] amigas, mas depois que já comprei" (F.M., 20 anos).

"Quando compro não, mas, às vezes, quando vou me arrumar para sair, sim" (P.W., 34 anos).

\subsection{Decisão de compra}

Em relação ao processo de compra, que, segundo Boone \& Kurtz (1998), envolve diversas decisões, as entrevistadas relataram como costumam escolher e comprar suas roupas. Observou-se que nenhuma das mulheres da geração $Y$ está acostumada a comprar online, pois elas gostam de experimentar as peças e avaliar o caimento, como destacado na citação abaixo de M.P. Já para a C.R., a internet pode servir como um veículo de consulta, o que reitera que as marcas utilizam influências de marketing para conquistar consumidores $(\mathrm{CHURCHILL} \mathrm{\&}$ PETER, 2007).

"Eu nunca comprei roupa online. Acho complicado, porque gosto de comprar uma coisa que fique bem, e só compro quando gosto muito, então preciso experimentar para saber isso" (M.P., 53 anos).

"Às vezes preciso de alguma coisa específica e aí eu gosto de olhar na internet primeiro, mas gosto de ir lá comprar, experimentar e ver como fica" (C.R., 43 anos).

A M.V. também relatou sofrer influências situacionais (CHURCHILL \& PETER, 2007), já que o ambiente lhe desperta vontade de consumir mesmo 
quando não há intenção prévia de compra. Ela relatou que, muitas vezes, estar passeando pelo shopping também instiga ao consumo, pois ela já se deparou em situações nas quais passando por alguma vitrine que chama a sua atenção, ela entra na loja e costuma achar não só a peça que tinha gostado, mas também outras coisas. Já a entrevista D.M. só entra nas lojas nas quais já está acostumada. Para ela, o atendimento também é importante.

"Vou sempre às lojas que gosto, uma média de a cada 10 dias, e já tenho uma vendedora fixa em cada loja" (D.M, 49 anos).

De forma geral, as entrevistadas da geração $Y$ costumam identificar a necessidade ou querer uma peça antes mesmo de compra-la. Para Boone \& Kurtz (1998), a percepção dessa diferença, ou seja, de estar em uma situação e querer alcançar outra, seja em ter uma roupa para uma festa por exemplo, é o primeiro fator motivacional da decisão de compra. A busca por informações antes do consumo, conforme argumentado por Churchill \& Peter (2007), também faz parte desse processo e nesse sentido, a internet foi citada como um veículo relevante para as mulheres de ambas as gerações. Porém, diferente dos hábitos apresentados pelas mulheres mais velhas, a F.M. e a A.L., da geração $Y$, gostam de comprar online, porque é uma forma de descobrir peças diferentes. A L.T. também busca se diferenciar por meio das peças que compra, contando que atualmente sua decisão é muito pautada na originalidade de cada roupa. Para a entrevistada, é justamente esse fator que ela mais procura quando vai às lojas, principalmente em viagens.

"Prefiro comprar online, gosto de encontrar uma marca que ninguém conhece,
então vejo bastante o Instagram, encontro alguma coisa e encomendo" (F.M., 20
anos).
"Adquiri uma filosofia que só posso comprar coisas que são muito diferentes de
tudo que já vi, penso que se eu usar isso de um jeito diferente pode dar certo. É
mais questão de identificação mesmo, quando eu olho pra uma peça e ela
desperta algo em mim que tem a ver com a personalidade" (A.L., 23 anos).

Diferente das demais, P.W. e T.L., que foram as entrevistadas mais velhas dentro da geração $Y$, destacaram que costumam entrar sempre nas mesmas lojas quando buscam peças básicas, nas quais já conhecem o estilo da marca e sabem quais peças de roupas Ihe "caem bem".

Quando questionadas sobre os fatores que influenciam na decisão da escolha da marca de moda, o estilo foi unanimidade para as entrevistadas das gerações $\mathrm{X}$ e $\mathrm{Y}$. Todas destacaram que é primordial gostar da roupa antes de considerar os demais fatores, o que demonstra que elas atribuem importância ao 
vestuário, que é parte de quem elas são. A escolha de que roupas vestir e do próprio estilo pode aproximar o eu real do eu ideal (HIGGINS, 1987), já que, segundo Braga (2008) as roupas podem fazer as pessoas serem notadas e admiradas. Em contrapartida, os demais aspectos mencionados pelas entrevistadas da geração $X$ envolvem questões mais objetivas e racionais, como qualidade das peças e conforto, enquanto que a L.T., F.M. e T.L., da geração X, reforçaram elementos ligados mais ligados ao conceito das marcas.

\footnotetext{
"Levo em consideração o estilo, o caimento, a qualidade do material. Existem lojas com roupas que se desfazem, por exemplo. Eu gosto de roupas que duram e são atemporais" (D.M., 49 anos).

"Estilo com certeza, mas qualidade também. Tem muitas lojas que têm um estilo legal, mas a roupa dura uma temporada" (C.R., 42 anos).

"Eu procuro muito saber o conceito, e saber o que a marca passa quando vende uma roupa, se é de certa forma original" (L.T., 20).

"Se a marca tem um posicionamento legal, tipo jovem e divertido, que provoca em mim certa curiosidade, eu vou querer consumir dela, me atrai muito. Acho que como qualquer expressão artística moda é isso" (F.M., 20 anos).

"Tem a questão do design, gosto de usar peças que tenham uma identidade" (T.L., 30 anos).
}

\subsubsection{Posicionamento de marca}

As perguntas realizadas neste bloco tiveram como objetivo identificar, de maneira geral, de que forma as entrevistadas percebem o posicionamento das marcas de moda. Buscou-se entender se é um aspecto relevante na escolha de suas roupas, já que, segundo Aaker (1998), esse conceito representa a imagem que a marca passa e pode influenciar decisões de consumo.

\subsubsection{Preocupação social}

Buscando iniciar a percepção das entrevistadas acerca da influência da imagem das marcas na decisão de compra. Por isso, este presente bloco do trabalho engloba uma questão relacionada à preocupação com o processo produtivo das roupas. Conforme já observado nos capítulos anteriores, marcas que são sensíveis à esse processo tendem a usar esse diferencial para se posicionar no mercado, ou seja, usar esses elementos como a sua identidade, buscando gerar percepções e criar uma imagem positiva nos consumidores (JUCÁ; JUCÁ, 2009). 
Ao serem perguntadas se o processo produtivo de fabricação das marcas é uma variável importante na consideração da compra, a maioria das entrevistadas de ambas as gerações respondeu de forma negativa, alegando não se orgulharem dessa postura, conforme ilustrado nas citações em seguida da L.M. e da L.T. Isso denota que as marcas escolhidas por essas consumidoras adotam diferentes benefícios para a construção do seu posicionamento (KELLER, 1993) e satisfazem necessidades simbólicas e intangíveis dessas mulheres que lhes são mais importantes do que o processo feito na confecção das roupas.

"Acho que não, mas acho que deveria me preocupar mais. Eu vejo valor em quem realmente consegue pensar nisso" (L.M., 48 anos).

"Queria muito dizer que sim, mas infelizmente não é um fator decisivo [pra] mim na hora de comprar" (L.T., 20 anos).

Ao contrário das demais, para a A.L., uma marca com responsabilidade social desperta mais interesse. Além disso, esse diferencial pode ser um fator de escolha quando ela está dividida entre roupas que gosta de lojas que apresentam esse tipo de preocupação com a produção, contra as que não. Ademais, ela sinaliza a compra de roupas de segunda mão como uma forma de consumo mais consciente.

\footnotetext{
"Hoje compro muito de brechó, que não é necessariamente de uma maca com responsabilidade social ou que eu queira apoiar, mas é uma forma sustentável de comprar e consumir. As marcas que gosto, mas são caras eu busco de segunda mão. Se quero comprar uma coisa especifica, um tênis preto, por exemplo, procuro primeiro em brechó ou site de revenda" (A.L., 23 anos).
}

As entrevistadas C.R. e a M.V., ambas da geração X, e F.M., da geração $Y$, comentaram sobre como essa problemática pode até influenciar momentaneamente, mas não é uma preocupação constante na compra das roupas. A entrevistada M.V. argumentou que gosta de acompanhar a proposta das marcas, apoiando iniciativas que valorizam tanto os profissionais da moda quanto a comunidade. Contudo, apesar disso, ela também destacou que continua comprando peças de marcas que não possuem essas iniciativas. A F.M. conta que mesmo após conhecer mais sobre o processo produtivo de marcas fast fashion, que vêm sendo alvo nos últimos anos de escândalos envolvendo a confecção de roupas de acordo com o Fashion Network (2016), não mudou seus hábitos de consumo. 


\begin{abstract}
"Obviamente que quando fico sabendo de algo ruim envolvendo animais e trabalho com crianças não vou ficar comprando, mas também acho que rapidamente você esquece dessas coisas" (C.R., 42 anos).

"Por exemplo, gosto de uma marca de São Paulo que sei que é feita com um processo bacana, valoriza a comunidade local, dá emprego, faz um trabalho social e a estilista é uma artista plástica - é uma combinação ideal que eu adoro. Mas, por outro lado, também compro em rede de lojas que tem um posicionamento diferente e que não tem nada de trabalho social no processo, e não me importo de comprar" (M.V., 55 anos).
\end{abstract}

"Não interfere na minha decisão de compra. Fiz um teste online daqueles para descobrir quantos escravos estão envolvidos para fazerem roupas que eu compro e na hora achei horrível, mas na semana seguinte comprei em fast fashion" (F.M., 20 anos).

\title{
4.2.1.2. Conteúdo de marca
}

De acordo com o Grupo Abril (2016), a geração X se importa mais com elementos mais tangíveis da roupa na escolha de uma marca, sendo menos influenciada por ideologias e posicionamentos das marcas. Essa questão se mostrou presente para todas as entrevistadas, como é possível perceber nas citações a seguir. Isso denota que a percepção de qualidade, que, segundo Garvin (1995) faz parte da construção da imagem de uma marca, é ligada à aspectos mais relacionados ao produto em si.

"Não muito, eu diria, não é uma coisa que me prende atenção. Escolho a marca puramente pelo estilo e visual da peça" (C.R., 42 anos).

"Não, não levo. Eu vejo por outra coisa, eu vejo a tendência, não me preocupo com significado mais da marca assim" (D.M., 49 anos).

"Assim, não me influencia totalmente, mas é uma coisa que eu até acho interessante, que eu eventualmente percebo" (M.P., 53 anos).

Ainda segundo a pesquisa publicada pelo Grupo Abril (2016), a geração Y apresenta um perfil mais leal às marcas, confiando mais em interações promovidas por elas. Quando as entrevistadas dessa faixa etária foram questionadas sobre considerarem o posicionamento da marca na escolha da compra, todas responderam que em alguma instância sim, com exceção da P.W. Para as entrevistadas F.M. e L.T., o posicionamento da marca gera identificação, e, consequentemente, maior vontade de consumir a marca. Segundo Keller \& Machado (2006), isso é uma evidência de brand equity positivo, ou seja, essas mulheres reagem melhor à uma roupa e são mais impulsionadas a compra-la por causa da sua marca. 


\begin{abstract}
"Muito, muito. Como a marca se porta, o que ela defende e as causas dela real me atraem muito. Se tem uma marca que não tem um posicionamento maneiro mas de certa forma me atrai, eu posso comprar, mas se ela tem um posicionamento irado eu quero comprar muito mais" (F.M., 20).

"Super, acho que a identificação com a marca vem muito daí, de ser uma marca que você sabe o que vai encontrar. Se a marca tem um posicionamento solidificado, isso vai gerar identificação. Para mim, a marca tem que chegar a ponto de ser um estilo de vida, sabe, conseguir tocar as pessoas muito mais do que vender roupas" (L.T., 20).
\end{abstract}

Ao serem questionadas se as marcas de moda preferidas pelas entrevistadas são as que elas efetivamente mais compram, foi possível identificar que algumas mulheres atribuem essa preferência por outros fatores que não a compra em si. Esse comportamento foi observado na M.V., da geração $X$, que tem uma marca de luxo como referência de estilo. Dentre as entrevistadas da geração $\mathrm{Y}$, a L.T. e a T.L. também discorreram sobre a questão de admiração por suas marcas de moda preferidas. Segundo Keller (1993), essa percepção está atrelada aos diferentes benefícios que uma marca pode oferecer. Nesse caso, além do benefício funcional, as entrevistadas também valorizam o simbólico, que são extrínsecos ao produto. Além disso, elas atribuem características a essas marcas, identificando qualidades como referência e arte, que refletem a personalidade que uma marca pode construir, segundo Pinho (1996).

"A Chanel é influência total de estilo, mas não é uma que posso comprar atualmente" (M.V., 55 anos).

"Acho que marca de moda não é só para você comprar. Se a marca tem originalidade ela vai criar um estilo, e o acesso que você tem a isso pode ser qualquer acesso, não precisa ser necessariamente a compra. As marcas ditam muita coisa" (L.T., 20 anos).

"Amo a Valentino, porque admiro a história da marca, gosto do processo criativo, inovação e das artes visuais" (T.L., 30 anos).

Por fim, visando aprofundar a interpretação sobre a relação dessas mulheres com as marcas além da compra da peça, buscou-se entender se elas acompanham essas marcas em outros momentos. Todas as entrevistadas da geração $\mathrm{Y}$ pontuaram o Instagram como o principal canal que acompanham das marcas. Apesar de não terem o hábito de comprar online, as entrevistas C.R. e M.P. disseram usar a rede social para ver os looks das marcas e então ir até a loja comprar. Elas também acreditam que esse tipo de conteúdo influencia o consumo, que não é só motivado pelo benefício funcional da peça (KELLER, 1993). Ou seja, é possível atestar que as entrevistadas sofrem a influência do conteúdo promovido pelas empresas de moda, em maior ou menor grau, durante 
o seu processo de decisão de compra de roupas, conforme Churchill \& Peter (2007).

"É, acompanho pelo Instagram só, é a única rede social que eu tenho. Mas assim, é um conteúdo puramente consumista de olhar um look, um lançamento, uma roupa nova, essas referências influenciam" (C.R., 42 anos).

"Sim, as lojas que eu gosto. Um veículo muito melhor que o Facebook é o Instagram, então eu sigo e fico de olho. Como eu disse, não compro online, mas posso querer a peça. Acho que seguir essas marcas influencia no meu consumo, porque fico sabendo das coisas antes de passar pela loja. Às vezes, você nem acha que precisa das roupas, mas vem a calhar" (M.P., 53 anos).

Para as entrevistadas da geração $\mathrm{Y}$, além do Instagram, mecanismos como blogs, catálogos, eventos promovidos pelas marcas, desfiles e sites foram mencionados. A F.M. destacou que conheceu uma das marcas que mais gosta, e que não tem loja física, por meio da internet. Já a A.L. disse que vem mudando seus hábitos em prol do consumo consciente. Ela, que apesar de se dizer bastante ligada à moda, parou de seguir e acompanhar essas marcas além do momento da compra.

"Sim, muito, muito. A LV Store, por exemplo, eu conheci no Instagram. Vejo tudo, campanhas, vídeos e site. Gosto muito da parte publicitária assim, gosto demais de ver o conteúdo que a marca produz" (F.M., 20 anos).

"Não acompanho mais, porque acredito que isso faz a gente consumir de forma negativa e inconsciente. Às vezes, não estamos precisando e somos influenciados, acho que é desnecessário. Parei de seguir recentemente todas as marcas no Instagram, porque você vê uma coisa e fica com vontade de comprar, isso não é saudável" (A.L., 23 anos). 


\section{Conclusão}

Esse estudo teve como objetivo entender a relação das mulheres das gerações $\mathrm{X}$ e $\mathrm{Y}$ com marcas de moda feminina. Para tanto, buscou-se identificar semelhanças e diferenças, entre as percepções de cada geração, acerca de questões como o significado da moda e das marcas, motivações para consumo e comportamento de compra.

Para uma contextualização inicial, buscou-se compreender mais a fundo o surgimento das marcas e sua importância na sociedade, problematizada por alguns autores, como por exemplo Pinho (1996). Nesse sentido, a história da moda, como argumenta os autores Braga (2008) e Caldas (1999), foi relevante para compreender o seu significado e impacto no cotidiano das mulheres, além de sua evolução em diferentes épocas e gerações.

Por meio das teorias de Aaker (1998) e Keller \& Machado (2006) sobre posicionamento de marca, almejou-se investigar o conceito de brand equity e os pilares que envolvem a construção de marcas fortes. Em seguida, os estudos de Higgins (1987) e Lipovetsky (2001) permitiram o conhecimento das motivações e necessidades dos consumidores, para então analisar o comportamento do consumidor e o processo de decisão de compra, de acordo com Solomon (2016) e Churchill \& Peter (2017). Por fim, buscando compreender as características das gerações, que, de acordo com Levy \& Weitz (2000) partilham de um mesmo estilo de vida e apresentam comportamentos semelhantes, foram analisadas pesquisas do Grupo Abril (2016) e de Fernandes (2015), principalmente relacionadas ao comportamento de consumo e envolvimento com marcas.

Para a elaboração do estudo, foi realizada uma pesquisa de caráter exploratório por meio de entrevistas qualitativas. Foram realizadas um total de dez entrevistas, com mulheres moradoras das zonas sul e oeste do Rio de Janeiro, dentre as quais cinco delas pertencentes à geração $X$, com idades entre 38 e 58 anos, e as demais cinco pertencentes à geração $Y$, com idades entre 19 e 37 anos. Todas as entrevistadas declararam se interessar por moda e foram selecionadas de forma aleatória, considerando apenas os critérios apresentados anteriormente. 
As entrevistas ocorreram por meio de um roteiro semi-estruturado. Elas foram gravadas e transcritas mediante o consentimento das mulheres, que tiveram 
sua identidade preservada por meio de suas iniciais. A análise de discurso foi utilizada para analisar as respostas, cujo os destaques serão apresentados a seguir.

A partir das entrevistas, pode-se constatar que a palavra roupa remete principalmente à moda e estilo para todas as entrevistadas, de ambas as gerações. Além disso, algumas entrevistadas da geração $X$ destacaram que as marcas de moda podem representar e transparecer mudanças na sociedade, estando sempre em transformação. Já para as mulheres entrevistadas da geração $\mathrm{Y}$, a força das marcas de moda vem além das roupas que produzem, e que essas marcas podem tanto causar afastamento quanto representar arte, inspiração, identidade e desejo.

De maneira generalizada, a forma de se vestir é considerada uma maneira de expressão para as entrevistadas, visto que as mulheres de ambas as gerações se preocupam com a opinião de amigos e familiares na hora de se vestir. Essa preocupação, no entanto, se dá apenas para a escolha das peças de roupa, e não pela escolha da marca de moda.

Em relação ao processo de compra, observou-se que nenhuma das entrevistadas da geração $X$ tem o hábito de comprar online, costume citado por algumas das entrevistadas da geração $Y$. No entanto, a internet, especialmente por meio da plataforma digital Instagram, é usada por todas como busca de referências antes da compra. Dentre os fatores considerados no momento da decisão, novamente o estilo foi apontado por todas as entrevistadas como o aspecto principal. Em seguida, as mulheres da geração $X$ demonstraram maior atenção com características mais ligados à peça, como qualidade e durabilidade, do que as mulheres da geração $\mathrm{Y}$, que destacaram maior preocupação com o conceito e essência das marcas.

A preocupação com os processos produtivos de confecção das roupas não influencia diretamente a escolha das marcas de nenhuma das entrevistadas. As mulheres de ambas as gerações relataram que gostariam de dar mais importância a essa questão, que ainda é pouco influente no consumo. Aprofundando a percepção sobre o posicionamento das marcas, foi possível observar que as entrevistadas da geração $Y$ têm mais vontade de consumir de marcas que possuem um posicionamento com as quais se identificam, enquanto as entrevistadas da geração $X$ disseram não se influenciarem tanto por aspectos das marcas de moda menos ligados às roupas. Ainda assim, todas as entrevistadas de ambas as gerações acreditam que são influenciadas, em maior 
ou menor grau, por conteúdo promovido por essas marcas em momentos além da compra, e acompanham-nas em pelo menos uma rede social.

Por fim, apesar de ter sido possível identificar algumas semelhanças e diferenças entre as entrevistadas das duas gerações, é evidente que a relação das mulheres com marcas de moda reflete o estilo de vida de cada uma, e não apenas tendências geracionais da sociedade. Ou seja, fatores como relações sociais, referências, abertura à estímulos e influências, bem como interesses, envolvimento com moda e valorização das marcas, refletem nas percepções sobre roupas, motivações e processo de decisão de compra dessas consumidoras.

\subsection{Direcionamento para estudos futuros}

Considerando aprofundamentos futuros, este estudo pode servir como base para a compreensão dos fatores que norteiam as tendências geracionais voltadas para o consumo de moda, já que a amostra deste não permite conclusões representativas. Podem ser exploradas pesquisas voltadas para a criação e representatividade do senso de moda para mulheres, pela ótica das influências sociais que recebem. Além disso, também é possível aprofundar o entendimento sobre a decisão de compra, avaliando os fatores que são mais considerados, dependendo da faixa etária de idade.

Ademais, um outro campo de estudo que pode ser fomentado por este presente trabalho é a influência da renda no significado da moda e comportamento de compra. Esse fator é parte importante da construção de personalidade das mulheres e pode trazer conclusões mais específicas a respeito de padrões de consumo e poder aquisitivo.

Para concluir, as perguntas e respostas obtidas com o presente estudo podem servir de referência para a criação de demais questionários, sejam roteiros aprofundados ou pesquisas quantitativas, buscando-se obter mais respostas acerca da percepção de mulheres sobre marca, moda e consumo. Essas informações serão relevantes não só para as empresas e profissionais do mercado de moda, que podem basear nesses estudos suas estratégias, mas também para os interessados em comportamento e interações sociais. 


\section{Referências Bibliográficas}

AAKER, D. Aaker on Branding. Nova lorque: Morgan James Publishing, 2014.

_. Brand Equity: Gerenciando o Valor da Marca. São Paulo: Negócio Editora, 1998. 309p.

BARBOSA, L.; CAMPBELL, C. Cultura, Consumo e Identidade. Rio de Janeiro: Editora FGV, 2006.

BASTOS, R. Geração X e Y. Comunidade ADM, 25 jun. 2012. Disponível em: $\quad<\mathrm{http}: / / w w w . a d m i n i s t r a d o r e s . c o m . b r / a r t i g o s / c a r r e i r a / g e r a c a o-x-e-$ y/64388/> Acesso em: 18 mai. 2018.

BRAGA, J. História da Moda. São Paulo: Anhembi Morumbi Ltda, 2008. BOONE, L.; KURTZ, D. Marketing Contemporâneo. São Paulo: Editora Cengage Learning, 2009.

_. Marketing Contemporâneo. 8a ed. Rio de Janeiro: Editora LTC, 1998.

CALDAS, D. Universo da moda: cursos on-line. São Paulo: Anhembi Morumbi, 1999.

CHURCHILL, G.A.; PETER, J. Marketing: Criando Valor para o Cliente. 7ํㅡㄹ ed. São Paulo: Ed. Saraiva, 2007.

COBRA, M. Marketing \& Moda. São Paulo: Ed. Senac, 2007.

FASHION NETWORK. Relatório Diz que Fornecedores da Gap, Zara e H\&M Exploram Trabalhadores. Fashion Network, 6 set. 2016. Disponível em: <http://pt.fashionnetwork.com/news/Relatorio-diz-que-fornecedoresda-Gap-Zara-e-H-M-exploramtrabalhadores,729076.htm|\#.WxMvcEgvzIW> Acesso em: 10 mai. 2018. FERNANDES, G. Gerações X Moda X Estilo. Dica de Stilo, 5 nov. 2015. Disponível em: <https://www.dicadestilo.com.br/singlepost/2015/11/5/Gera\%C3\%A7\%C3\%B5es-X-Moda-X-Estilo> Acesso em: 10 mai. 2018. 
GARVIN, D. A. Competindo Nas Oito Dimensões da Qualidade.In: SVIOKLA, J. J.; SHAPIRO, B. P. (Eds). Mantendo Clientes: a Harvard Business Review book. São Paulo: Makron Books, 1995.

GIL, A.C. Métodos e Técnicas de Pesquisa Social. São Paulo: Atlas, 1999.

GODOY, A. S. Introdução à Pesquisa Qualitativa e suas Possibilidades. RAE- Revista de Administração de Empresas. São Paulo: v.35, n.2, p. 57-63, abr.

1995.

GRUPO ABRIL. O "X" da Questão: um olhar inédito sobre uma geração que influencia, consome e paga a conta. São Paulo: Grupo Abril, 2016. Disponível em: <https://indd.adobe.com/view/c910eae9-8f05-4b4c-9996751c3ef7e96d> Acesso em: 20 mai. 2018.

HEINE, K. The Personality of Luxury Fashion Brands. Journal of Global Fashion Marketing, vol. 1, n.3, 2010, p.154-163.

JEFFREY GROUP BRAZIL. Pesquisa" Bens de Consumo Conectados" de 2016 da Salesforce Detalha Comportamento dos Consumidores com as Marcas de Varejo. Jeffrey Group Brazil site, 13 jul. 2016. Disponível em: $<$ https://www.segs.com.br/info-ti/24819-pesquisa-bens-de-consumoconectados-de-2016-da-salesforce-detalha-comportamento-dosconsumidores-com-as-marcas-do-varejo.html> Acesso em: 19 mai. 2018. JUCÁ, F.; JUCÁ, R. Branding 101: O guia básico para gestão de marcas de produtos. Portal Mundo Markenting, 10 out. 2009. Disponível em: <https://s3.amazonaws.com/MYBRAINSTORMWEBSITE/uploads/idea_att achment/file/19/branding101.pdf>. Acesso em: 03 mai. 2018.

KAPFERER, J. N. The New Strategic Brand Management: Creating and Sustaining Brand Equity Long Term. $4^{\mathrm{a}}$ ed. Londres: Kogan Page, 2008.

Disponível

em:

$<$ https://www.academia.edu/12869300/The_New_Strategic_Brand_Manag ement_-_Jean_Noel_Kapferer_PDF_?ends_sutd_reg_path=true>. Acesso em: 31 mai. 2018.

KELLER, K. L. Conceptualizing, Measuring and Managing Customer: based brand equity. Journal of Marketing, vol. 57, n.1, jan. 1993, p.1-22. 
KELLER, K. L.; MACHADO, M. Gestão Estratégica de Marcas. São Paulo: Person Prentice Hall, 2006.

KOTLER, P; ARMStRONG, G. Princípios de Marketing. Prentice-Hall do Brasil Ltda. Edições, 1999.

KOTLER, P. Marketing de A a Z: 80 conceitos que todo profissional precisa saber. $7^{\underline{a}}$ ed. Rio de Janeiro: Editora Elsevier, 2003.

KOTLER, P; ARMStRONG, G. Administração de Marketing. 12. ed. São Paulo: Prentice Hall; 2005.

LEVY, M.; WEITZ, B. A. Administração de Varejo. São Paulo: Atlas, 2000.

LIPOVETSKY, G. O Império do Efêmero: a moda e seu destino nas sociedades modernas. São Paulo: Cia das Letras, 2001.

MANZINI, E. J. Entrevista Semi-Estruturada: análise de objetivos e de roteiros. Seminário Internacional Sobre Pesquisa e Estudos Qualitativos. Anais A Pesquisa Qualitativa em Debate, Bauru, USC, 2004. Disponível em:

<https://www.marilia.unesp.br/Home/Instituicao/Docentes/EduardoManzini /Manzini_2004_entrevista_semi-estruturada.pdf> Acesso em: 10 mai. 2018.

MATTAR, F. N. Pesquisa de Marketing: metodologia, planejamento. $6^{\underline{a}}$ ed. São Paulo: Atlas, 2005.

MALHOTRA, N. K. Introdução a Pesquisa de Marketing. São Paulo: Pearson Prentice Hall, 2005.

MESQUITA, C. O Império do Estilo. IARA - Revista de Moda, Cultura e Arte, vol. 2, n.2, out.-dez. 2009. Disponível em: <http://www1.sp.senac.br/hotsites/blogs/revistaiara/wp-

content/uploads/2015/01/02_IARA_vol2_n2_Dossie.pdf> Acesso em: 11 mai. 2018.

MICHAELIS. Definição da palavra "moda". Michaelis, Dicionário Brasileiro de Língua Portuguesa, 2018. Disponível em: $<$ http://michaelis.uol.com.br/busca? $r=0 \& f=0 \& t=0 \&$ palavra=moda $>$ Acesso em: 12 mai. 2018.

NIELSEN. Tendências de comportamento de consumo para a mulher brasileira. $\quad$ Nielsen, 2016 Disponível em: < 
http://www.nielsen.com/br/pt/insights/news/2016/Tendencias-de-consumopara-a-mulher-brasileira.html>. Acesso em: 3 mai. 2018

OGILVY, D. Confissões de Um Publicitário. Rio de Janeiro: Bertrand, 2011.

OLIVEIRA, B.; CAMPOMAR, M. C. Revisitando o Posicionamento em Marketing. REGE - Revista de Gestão, vol. 14, n.1, 2007. Disponível em: <http://www.revistas.usp.br/rege/article/view/36589 >. Acesso em: 03 mai. 2018.

PELLETIER, M. O Império das Marcas [Empire des marques]. Documentário. Ottawa, Canadá: The Multimedia Group of Canada, 2002. PINHO, J. B. O Poder das Marcas. São Paulo: Summus Editorial, 1996. RIES, A.; TROUT, J. Posicionamento: a Batalha por sua Mente. $1^{\underline{a}}$ ed. São Paulo: M. Books, 2009.

ROSSITER, J; BELLMAN, S. Emotional branding pays off: how brands meet share of requirement through bonding, companionship and love. University of Wollongong, 2012. Disponível em:< http://ro.uow.edu.au/cgi/viewcontent.cgi?article=3915\&context=commpape rs>. Acesso em: 20 mai. 2018.

SAMPAIO, R. Propaganda de A a Z: como usar a propaganda para construir marcas e empresas de sucesso. Rio de Janeiro: Campus / ABP, 1999.

SHETH, J. N.; MITTAL, B.; NEWMAN, B. I. Comportamento do Cliente: indo além do comportamento de do consumidor. São Paulo: Atlas, 2001.

SMOLA, K. W.; SUTTON, C. D. Generational Differences Revisiting Generational Work Values for the New Millennium. Journal of Organizational Behavior, v. 23, n. 4, 2002.

SOLOMON, M. R.; O Comportamento do Consumidor: comprando, possuindo e sendo. 11르 ed. Porto Alegre: Bookman, 2016.

VERGARA, C. S. Métodos de Pesquisa em Administração. São Paulo:

Editora Atlas S.A, 2005.

WOMENS MARKETING. Reportagem de 2015. Disponível em <http://www.womensmarketing.com/> Acesso em: 10 nov. 2017. 


\section{Anexo}

\section{Roteiro de Entrevista Qualitativa:}

1. Ao ouvir falar em "roupa", que expressões e palavras vem a sua à sua mente?

2. Descreva seu processo usual de compra de roupas.

3. O que as marcas de moda representam para você?

4. Que fatores você leva em consideração na escolha de uma marca de moda? Por quê?

5. Qual aspecto, entre preço, qualidade, conforto, estilo, marca, tendência, responsabilidade socioambiental e durabilidade, você considera mais importante na escolha de roupas? Por quê?

6. Você se preocupa com a fabricação e com o processo produtivo das marcas das roupas que compra? Até que ponto isso influencia na sua decisão de compra?

7. Você leva em consideração a opinião de amigos e parentes quando compra uma marca de roupa? Por quê?

8. Você leva em consideração o "significado" de uma marca de moda na escolha da compra? Entenda por "significado" o que a marca representa, o que ela transmite na sua comunicação, as causas que ela apoia...

9. Cite as suas 3 marcas de moda preferidas e justifique. Elas são as que você mais compra? Por quê?

10. Você acompanha as suas marcas de moda preferidas além do momento da compra? Como? (Ex: propagandas, ações promovidas, mídias sociais, eventos, parcerias...)

11. Que tipo de roupa e marca você acha que é preferida pela geração $X$ ( 38 a 58 anos) ? E da geração $Y$ (19 a 37)? 